\title{
Frequent somatic loss of BRCA1 in breast tumours from BRCA2 germ-line mutation carriers and vice versa
}

\author{
S Staff', JJ Isola', O Johannsson ${ }^{2}$, Å Borg² and MM Tanner ${ }^{1}$ \\ ${ }^{1}$ Laboratory of Cancer Genetics, Institute of Medical Technology, University Hospital of Tampere, FIN-33014 University of Tampere, Finland; \\ ${ }^{2}$ Department of Oncology, University Hospital, S-221 85 Lund, Sweden
}

\begin{abstract}
Summary Breast cancer susceptibility genes $B R C A 1$ and $B R C A 2$ are tumour suppressor genes the alleles of which have to be inactivated before tumour development occurs. Hereditary breast cancers linked to germ-line mutations of BRCA1 and BRCA2 genes almost invariably show allelic imbalance (Al) at the respective loci. BRCA1 and BRCA2 are believed to take part in a common pathway in maintenance of genomic integrity in cells. We carried out Al and fluorescence in situ hybridization (FISH) analyses of $B R C A 2$ in breast tumours from germline $B R C A 1$ mutation carriers and vice versa. For comparison, 14 sporadic breast tumours were also studied. 8 of the $11(73 \%)$ informative $B R C A 1$ mutation tumours showed Al at the BRCA2 locus. $53 \%$ of these tumours showed a copy number loss of the BRCA2 gene by FISH. 5 of the $6(83 \%)$ informative $B R C A 2$ mutation tumours showed Al at the BRCA1 locus. Half of the tumours (4/8) showed a physical deletion of the BRCA1 gene by FISH. Combined allelic loss of both BRCA1 and BRCA2 gene was seen in 12 of the $17(71 \%)$ informative hereditary tumours, whereas copy number losses of both BRCA genes was seen in only $4 / 14(29 \%)$ sporadic control tumours studied by FISH. In conclusion, the high prevalence of $\mathrm{Al}$ at $B R C A 1$ in BRCA2 mutation tumours and vice versa suggests that somatic events occurring at the other breast cancer susceptibility gene locus may be selected in the cancer development. The mechanism resulting in Al at these loci seems more complex than a physical deletion. () 2001 Cancer Research Campaign http://www.bjcancer.com
\end{abstract}

Keywords: BRCA1; BRCA2; allelic imbalance; LOH; FISH

Approximately $5-10 \%$ of breast cancer is due to inherited predisposition (Miki et al, 1994). Germ-line mutations in the two identified susceptibility genes, BRCA1 (Miki et al, 1994) and BRCA2 (Wooster et al, 1994; Tavtigian et al, 1996) are responsible for a large proportion of hereditary breast cancer (Szabo and King, 1997). Both BRCA1 and BRCA2 are considered as classical tumour suppressor genes and therefore inactivation of both alleles is required for cancer initiation. Although no sequence homology has been found between BRCA1 and BRCA2, they share many functional properties (reviewed in Welcsh et al, 2000).

Almost all the tumours from germ-line $B R C A 1$ and $B R C A 2$ mutation carriers show loss of heterozygosity $(\mathrm{LOH})$ or $\mathrm{AI}$ at the corresponding loci (Smith et al, 1992; Neuhausen and Marshall, 1994; Collins et al, 1995; Gudmunsson et al, 1995; Staff et al, 2000), which is in accordance with the lost tumour suppressor function. Due to several functional parallels between $B R C A 1$ and $B R C A 2$, we studied the possible somatic aberrations of $B R C A 1$ by AI and FISH in breast cancer tumours from germ-line $B R C A 2$ mutation carriers, and vice versa. The possible concomitant somatic aberrations of the $B R C A 1$ and BRCA2 genes were also studied in 14 sporadic breast cancer samples by FISH. We have previously shown (Staff et al, 2000) that unlike in hereditary BRCA $1 / 2$ tumours, the allelic imbalance at BRCA1/2 loci is almost always a result of a physical deletion in sporadic tumours. Therefore, physical deletion of the $B R C A$

Received 2 March 2001

Revised 2 July 2001

Accepted 2 July 2001

Correspondence to: S Staff, Laboratory of Cancer Genetics, Institute of Medical Technology, Lenkkeilijankatu 6, 33014 University of Tampere, Finland; E-mail: ss59025@uta.fi genes detected by FISH reflects the allelic imbalance of the $B R C A 1 / 2$ loci in sporadic tumours (Staff et al, 2000).

\section{MATERIALS AND METHODS}

\section{Patients and tumour samples}

17 primary breast cancer tumours from germ-line $B R C A 1$ mutation carriers and 8 primary breast tumours from germ-line $B R C A 2$ mutation carriers were derived from the Department of Oncology, University of Lund. 14 primary sporadic breast cancer tumours were obtained from Tampere University Hospital. The tumour samples were snap-frozen and stored at $-70^{\circ} \mathrm{C}$ until used for AI and FISH analyses.

Genomic DNA was extracted from available blood samples of the $13 B R C A 1$ and 6 BRCA2 germ-line mutation carriers by standard methods. One $B R C A 1$ patient had 2 separate tumours $(\mathrm{Ca}$ 8571 and Ca 13996; Table 1), which were both analysed. BRCA1 patients with tumours Ca 14090 and Ca 14007 (Table 1) were relatives, but none of the other $B R C A 1$ patients were directly related. One BRCA2 patient had also 2 separate tumours $(\mathrm{Ca} 11900$ and 14 486; Table 2). BRCA2 patients with tumours $\mathrm{Ca} 7936$ and $\mathrm{Ca}$ 11506 were from the same family, similarly as patients with tumours Ca 11787 and $\mathrm{Ca} 13816$ (Table 2). BRCA1 and BRCA2 mutation analyses have been described previously (Johansson et al, 1996; Håkansson et al, 1997; Tables 1 and 2).

\section{PCR microsatellite analysis}

Polymerase chain reaction (PCR) was used to detect AI at polymorphic microsatellite markers by comparing the allelic patterns 
Table 1 Copy number aberrations of $B R C A 2$ by FISH and Al in 17 breast cancers from germ-line BRCA1 mutation carriers

\begin{tabular}{|c|c|c|c|c|c|c|c|c|c|}
\hline Tumour & $\begin{array}{l}\text { BRCA1 } \\
\text { mutation }\end{array}$ & $\begin{array}{l}\text { Result of the } \\
\text { BRCA1 mutation }\end{array}$ & $\begin{array}{l}\text { Al at the } \\
\text { BRCA1 } \\
\text { locus }^{\text {a }}\end{array}$ & $\begin{array}{l}\text { Al at the } \\
\text { BRCA2 } \\
\text { locus }^{\text {b }}\end{array}$ & $\begin{array}{c}\text { DNA } \\
\text { Index }\end{array}$ & $\begin{array}{l}\text { Mean copy } \\
\text { number/cell } \\
\text { of BRCA2 } \\
( \pm \text { SEM) }\end{array}$ & $\begin{array}{c}\text { Mean copy } \\
\text { number/cell of } \\
13 q \text { reference } \\
\text { probe }( \pm S E M)\end{array}$ & $\begin{array}{c}\text { Mean copy } \\
\text { number } \\
\text { ratio (BRCA2/ } \\
\text { 13q reference probe) }\end{array}$ & $\begin{array}{l}\text { Interpretation } \\
\text { of the BRCA2 copy } \\
\text { number by FISH }\end{array}$ \\
\hline Ca 12421 & 2594delC & Ile845Stop & NA & NA & 1.56 & $3.84(0.11)$ & $2.55(0.09)$ & 1.51 & 3:4 BRCA2 gain \\
\hline Ca 11808 & 3829delT & Leu1263Stop & Yes & Yes & 1.0 & $1.18(0.09)$ & $1.20(0.09)$ & 0.98 & Monosomy of 13q \\
\hline Ca 09252 & 2594delC & Ile845Stop & Yes & Yes & 1.8 & $2.47(0.11)$ & $3.45(0.10)$ & 0.72 & 3:2 BRCA2 deletion \\
\hline Ca 14007 & 3172ins5 & Thr1025Stop & Yes & Yes & 1.53 & $1.43(0.08)$ & $2.71(0.10)$ & 0.53 & 3:2 BRCA2 deletion \\
\hline Ca 10581 & $1806 \mathrm{C} \rightarrow \mathrm{T}$ & Gln563Stop & Yes & $\mathrm{NI}$ & 1.73 & $2.17(0.12)$ & $3.66(0.16)$ & 0.59 & 4:2 BRCA2 deletion \\
\hline Ca 12224 & $1806 \mathrm{C} \rightarrow \mathrm{T}$ & GIn563Stop & Yes & Yes & 1.52 & $2.10(0.10)$ & $2.50(0.11)$ & 0.84 & Large deletion at $13 q^{\text {e.f }}$ \\
\hline Ca 14510 & $300 \mathrm{~T} \rightarrow \mathrm{G}$ & Cys61Gly & Yes & Yes & 2.46 & $2.43(0.17)$ & $2.53(0.15)$ & 0.96 & Large $13 q$ deletion ${ }^{f}$ \\
\hline Сa 10360 & 3172ins5 & Thr1025Stop & Yes & Yes & 1.7 & $1.80(0.09)$ & $1.94(0.07)$ & 0.98 & Large $13 q$ deletion ${ }^{\dagger}$ \\
\hline Сa 13812 & $4808 \mathrm{C} \rightarrow \mathrm{G}$ & Glu1115Stop & Yes & $\mathrm{NI}$ & 1.87 & $1.82(0.08)$ & $1.98(0.08)$ & 0.92 & Large $13 q$ deletion ${ }^{\dagger}$ \\
\hline Сa 13714 & 5382insC & Glu1829Stop & Yes & No & 2.48 & $3.30(0.18)$ & $3.06(0.09)$ & 1.08 & Large $13 q$ deletion ${ }^{\dagger}$ \\
\hline Сa 13996 & $1806 \mathrm{C} \rightarrow \mathrm{T}$ & Gln563Stop & Yes & Yes & 1.11 & $1.84(0.09)$ & $2.24(0.10)$ & 0.82 & No relative copy number change \\
\hline Ca 14970 & 2594delC & Ile845Stop & Yes & Yes & 1.00 & $2.26(0.11)$ & $2.21(0.09)$ & 1.02 & No relative copy number change \\
\hline Ca 11394 & $1177 \mathrm{G} \rightarrow \mathrm{A}$ & Trp353Stop & NA & NA & 1.0 & $2.40(0.14)$ & $2.95(0.14)$ & 0.81 & No relative copy number change \\
\hline Ca 08822 & 1201del11 & Ser361Stop & Yes & NA & 1.69 & $3.16(0.16)$ & $3.35(0.11)$ & 0.94 & No relative copy number change \\
\hline Ca 10697 & Linkage + & & Yes & NA & 1.51 & $3.11(0.17)$ & $3.18(0.15)$ & 0.98 & No relative copy number change \\
\hline Ca 14090 & 3172ins5 & Thr1025Stop & Yes & No & 1.00 & $2.08(0.10)$ & $2.19(0.08)$ & 0.95 & No relative copy number change \\
\hline Ca 08571 & $1806 \mathrm{C} \rightarrow \mathrm{T}$ & Gln563Stop & Yes & No & NA & $3.20(0.19)$ & $3.35(0.17)$ & 0.96 & No relative copy number change \\
\hline
\end{tabular}

Copy numbers represent the mean of at least 50 nuclei counted from each sample. (NA = Not available, $\mathrm{NI}=$ Not informative) aPreviously published (Staff et al, 2000). ${ }^{\mathrm{b}} \mathrm{Allelic}$ imbalance was analysed using microsatellite markers $13 \mathrm{~S} 267$ and $13 \mathrm{~S} 260$. Al was stated if at least one of the markers used indicated imbalance (compared to normal DNA) of more than $25 \%$ between the alleles in tumour sample. ${ }^{\circ} \mathrm{DNA}$ index by DNA flow cytometry. 'Deletion was defined if the copy number ratio was 0,80 or less. Gain was defined if the copy number ratio was 1.30 or more. e3:2 BRCA2 deletion in a subpopulation. 'When DNA-index was used as copy number reference, the copy number ratios indicated a large deletion in $13 q$ spanning both BRCA2 and ETB genes. When $13 q$ probe (ETB) was used as a reference probe, no BRCA2 gene copy number change was revealed.

Table 2 Copy number aberrations of BRCA1 by FISH and Al in 8 breast cancers from germ-line BRCA2 mutation carriers

\begin{tabular}{|c|c|c|c|c|c|c|c|c|c|}
\hline Tumour & $\begin{array}{l}\text { BRCA2 } \\
\text { mutation }\end{array}$ & $\begin{array}{c}\text { Result of } \\
\text { the BRCA2 } \\
\text { mutation }\end{array}$ & $\begin{array}{l}\text { Al at the } \\
\text { BR TCA2 } \\
\text { locus }^{\mathrm{a}}\end{array}$ & $\begin{array}{l}\text { Al at the } \\
\text { BRCA1 } \\
\text { locus }^{\text {b }}\end{array}$ & $\begin{array}{c}\text { DNA } \\
\text { index }^{c}\end{array}$ & $\begin{array}{c}\text { Mean copy } \\
\text { number/cell of } \\
\text { BRCA1 ( } \pm \text { SEM) }\end{array}$ & $\begin{array}{c}\text { Mean copy } \\
\text { number/cell of } \\
\text { chr } 17 \text { centromere } \\
( \pm \text { SEM) }\end{array}$ & $\begin{array}{c}\text { Mean copy } \\
\text { number ratio } \\
\text { (BRCA1/ chr } 17 \text { cen) }\end{array}$ & $\begin{array}{l}\text { Interpretation of the BRCA1 } \\
\text { copy number by FISH }\end{array}$ \\
\hline Ca 11900 & 2024del5 & Ser599Stop & Yes & Yes & 1.89 & $2.27(0.15)$ & $5.44(0.27)$ & 0.42 & 5:2 BRCA1 deletion \\
\hline Ca 10588 & $4486 \mathrm{delG}$ & Val1447Stop & NA & NA & 1.07 & $1.10(0.04)$ & $2.0(0.07)$ & 0.55 & 2:1 BRCA1 deletion \\
\hline Ca 13816 & $3058 \mathrm{~A} \rightarrow \mathrm{T}$ & Lys944Stop & Yes & Yes & 1.00 & $1.18(0.05)$ & $1.0(0.00)$ & 1.18 & Monosomy of chromosome 17 \\
\hline Ca 14486 & 2024del5 & Ser599Stop & Yes & Yes & 1.87 & $2.14(0.11)$ & $4.42(0.20)$ & 0.48 & 4:2 BRCA1 deletion \\
\hline Ca 07936 & $6293 \mathrm{C} \rightarrow \mathrm{G}$ & Ser2022Stop & No & Yes & NA & $2.19(0.13)$ & $2.34(0.14)$ & 0.94 & No relative copy number change \\
\hline Ca 11721 & 5445del5 & Tyr1739Stop & NA & NA & 1.00 & $3.04(0.18)$ & $3.68(0.13)$ & 0.83 & No relative copy number change \\
\hline Ca 11787 & $3058 \mathrm{~A} \rightarrow \mathrm{T}$ & Lys944Stop & Yes & Yes & 1.94 & $4.08(0.12)$ & $3.92(0.09)$ & 1.04 & No relative copy number change \\
\hline Ca 11506 & $6293 \mathrm{C} \rightarrow \mathrm{G}$ & Ser2022Stop & Yes & No & 1.96 & $2.77(0.12)$ & $2.27(0.07)$ & 1.22 & No relative copy number change \\
\hline
\end{tabular}

Copy numbers represent the mean of at least 50 nuclei counted from each sample. (NA = Not available). aPreviously published (Staff et al, 2000). ${ }^{\mathrm{b} A l l e l i c}$ imbalance was analysed using microsatellite markers $17 \mathrm{~S} 1322$ and $17 \mathrm{~S} 855$. Al was stated if at least one of the markers used indicated imbalance (compared to normal DNA) of more than $25 \%$ between the alleles in tumour sample. ${ }^{\mathrm{D} D N A}$ index by DNA flow cytometry. ${ }^{d}$ Deletion was defined if the copy number ratio was 0.80 or less. Gain was defined if the copy number ratio was 1.30 or more. 
of tumour and blood DNA. Two BRCA1 intragenic markers (D17S855 and D17S1322) (Albertsen et al, 1994) and 2 markers physically linked to BRCA2 (D13S260 and D13S267) (Wooster et al, 1994) were analysed using primers with published sequence (Gyapay et al, 1994) (Research Genetics, Huntsville, AL, USA). The PCR reactions were carried out as previously described (Staff et al, 2000). $1 \mu \mathrm{l}$ of the PCR product was analysed by capillary electrophoresis using ABI PRISM ${ }^{\text {TM}} 310$ Genetic Analyser and GeneScan 2.1 Software according to the manufacturer's instructions (Perkin-Elmer). For the informative heterozygous markers, the AI was determined by calculating ratio of the alleles $(\mathrm{L})$ as previously described (Staff et al, 2000). If $\mathrm{L}<0.75$ or $\mathrm{L}>1.33$, then one of the alleles has decreased more than $25 \%$ resulting in AI, as previously defined (Kerangueven et al, 1997).

\section{FISH analyses}

FISH analyses were performed using gene-specific PAC probes for BRCA1 (PAC 103014) and BRCA2 (PAC 92M18) genes. The specificity of these clones has previously been confirmed (Staff et al, 2000). Chromosome 17 centromere probe (p17H8) was used as a copy number reference for $B R C A 1$. For $B R C A 2$, a PAC probe specific for the $E T B$ gene (at 13q22) was used as a reference, because specific centromere probe for chromosome 13 is not available. The hybridization efficiency of the probes was tested in a non-malignant breast sample. Hybridization and detection were performed as previously described (Tanner et al, 1998; Staff et al, 2000). Hybridization signals from 50-100 nuclei were scored to assess the copy number of the $B R C A 1$ and $B R C A 2$ genes. Deletion of the $B R C A$ genes was defined as an average ratio $\leq 0.80$ of $B R C A 1 / 2$ signals relative to chromosome 17 centromere signals or $E T B$ signals, respectively. Gain was defined as an average ratio of $\geq 1.30$. Digital images were taken with a Hamamatsu 9585 camera (Hamamatsu, Hamamatsu City, Japan) operated via ISIS image analysis software (MetaSystems, Altslussheim, Germany).

\section{RESULTS}

\section{$B R C A 1$ and $B R C A 2$ tumours}

11 out of 13 BRCA1 mutation carriers with available blood samples were informative, i.e. they were heterozygous for at least one of the two BRCA2 markers. AI at BRCA2 was found in 8 of the 11 (73\%) informative cases (Figure 1, Table 1). All the 17 BRCA1 tumours were analysed for the $B R C A 2$ gene copy number by FISH. 3 tumours showed a clear physical interstitial deletion of the $B R C A 2$ gene when $B R C A 2$ signals were compared to the reference gene signal counts (ETB gene at 13q22) (Figure 1, Table 1). If the overall ploidy level (= DNA index by flow cytometry) was used as a $B R C A 2$ copy number reference, 6 additional tumours showed a loss of $B R C A 2$. This suggests a large deletion at $13 \mathrm{q}$ comprising both $E T B$ and $B R C A 2$ genes in all but one of these tumours
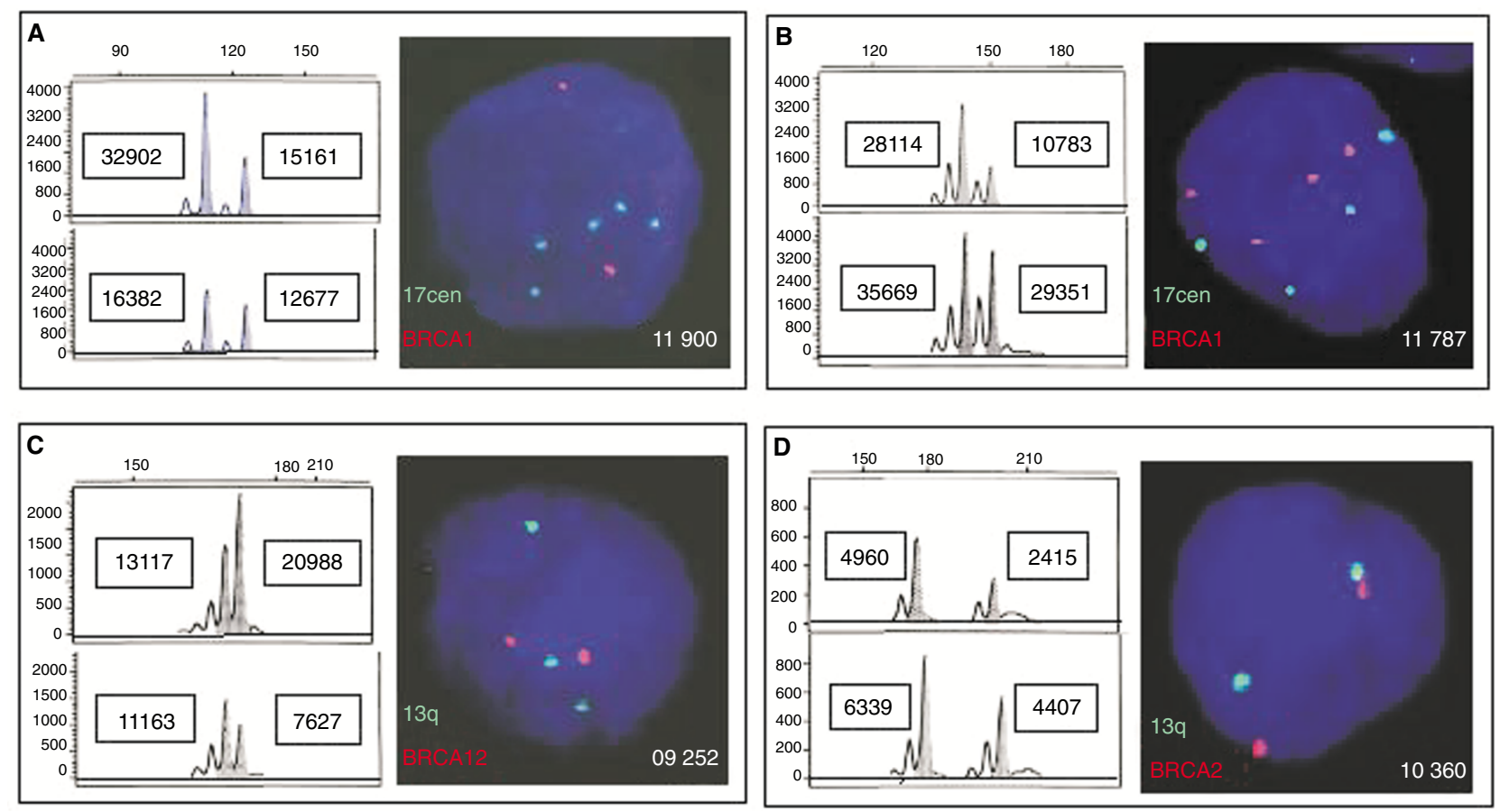

Figure 1 Examples of the assessment of allelic imbalance (AI) by automated DNA sequencer and two-colour FISH of BRCA1, chromosome 17 centromere $B R C A 2$ and $E T B$ (13q reference probe). The Al and FISH analyses of the same tumour are presented next to each other so that $\mathrm{Al}$ analysis is shown in the left. The fragment analysis of PCR products is shown from tumour DNA (top rows) and from matched blood DNA (bottom rows). Size of PCR products (in base pairs) is shown on the X-axis, and the peak heights in fluorescence units are shown on the Y-axis. The alleles in the normal DNA and the corresponding peaks in the tumour DNA are shown in grey. The corresponding allele peak areas in informative tumours are presented in boxes next to the peaks. In FISH images, the probes are visualised in green and red colours (fluorescein and Texas Red, respectively). The probes are marked with the corresponding colour in each panel. The nuclei were counterstained with DAPI (blue). The case numbers are marked in each panel with white colour texture. (A) Tumour 11900 from germ-line BRCA2 mutation carrier showing Al at the BRCA1 locus with marker D17S1322 and physical deletion of BRCA1 by FISH. (B) Tumour 11787 from germ-line BRCA2 mutation carrier demonstrating Al at the BRCA1 locus with marker D17S855 and no relative $B R C A 1$ gene copy number change by FISH. (C) Tumour 09252 from germ-line BRCA1 mutation carrier showing Al at the BRCA2 locus with marker D13S260 and physical deletion of BRCA2 by FISH. (D) Tumour 10360 from germ-line BRCA1 mutation carrier showing Al at the BRCA2 locus with marker D13S260 and no BRCA2 gene copy number change relative to $13 q$ reference probe by FISH 
Table 3 Summary of FISH analyses of both BRCA1 and BRCA2 genes in 14 sporadic breast cancers

\begin{tabular}{|c|c|c|}
\hline $\begin{array}{l}\text { Sporadic } \\
\text { cases }\end{array}$ & $\begin{array}{l}\text { Interpretation of BRCA1 } \\
\text { copy number by FISH* }\end{array}$ & $\begin{array}{l}\text { Interpretation of BRCA2 } \\
\text { copy number by FISH* }\end{array}$ \\
\hline Case $1^{\star \star}$ & 4:2 BRCA1 deletion & 3:2 BRCA2 deletion \\
\hline Case $2^{\star *}$ & 4:2 BRCA1 deletion & 3:2 BRCA2 deletion \\
\hline Case 3 & No relative BRCA1 copy number change & Monosomy of chromosome 13 \\
\hline Case 4 & No relative BRCA1 copy number change & No relative BRCA2 copy number change \\
\hline Case $5^{\star *}$ & Monosomy of chromosome 17 & Monosomy of chromosome 13 \\
\hline Case 6 & No relative BRCA1 copy number change & 3:2 BRCA2 deletion \\
\hline Case $7^{\star *}$ & 4:2 BRCA1 deletion & 5:3 BRCA2 deletion \\
\hline Case 8 & No relative BRCA1 copy number change & 3:2 BRCA2 deletion \\
\hline Case 9 & No relative BRCA1 copy number change & No relative BRCA2 copy number change \\
\hline Case 10 & 2:1 BRCA1 deletion & No relative BRCA2 copy number change \\
\hline Case 11 & No relative BRCA1 copy number change & No relative BRCA2 copy number change \\
\hline Case 12 & 2:1 BRCA1 deletion & No relative BRCA2 copy number change \\
\hline Case 13 & No relative BRCA1 copy number change & No relative BRCA2 copy number change \\
\hline Case 14 & No relative BRCA1 copy number change & No relative BRCA2 copy number change \\
\hline
\end{tabular}

*Deletion was defined if the copy number ratio (BRCA1 gene copy number signals/chromosome 17 centromere signals or $B R C A 2$ gene copy number signals/ETB gene copy number signals) was 0.80 or less. ${ }^{*}$ Concomitant loss of $B R C A 1$ and $B R C A 2$.

(Ca 12 224). In Ca 12 224, ETB copy number loss was present only in approximately $50 \%$ of the tumour cells (ETB gene copy number average 2.50) suggesting an interstitial deletion of $B R C A 2$ gene in a subpopulation. Thus, loss of at least one copy of the $B R C A 2$ gene was present in $53 \%(9 / 17)$ of the $B R C A 1$ tumours.

All but one of the informative $B R C A 1$ tumours showing change in the relative $B R C A 2$ gene copy number showed also AI at the $B R C A 2$ locus (Figure 1, Table 1). 7 out of $17(41 \%)$ of the BRCA1 tumours did not reveal any relative $B R C A 2$ copy number change, although 2 of them (i.e. 2 out of 4 informative cases) showed AI of $B R C A 2$ (Table 1). One tumour $(1 / 17 ; 6 \%)$ showed a copy number gain of the BRCA2 gene but this tumour was not available for AI analysis (Table 1).

5 of the available $6 B R C A 2$ tumours $(83 \%)$ showed $\mathrm{AI}$ at the BRCA1 locus (Figure 1, Table 2). All the tumours were also analysed by FISH, and 4 of them $(4 / 8 ; 50 \%)$ showed a physical deletion of the $B R C A 1$ gene (Figure 1, Table 2). All the informative cases with deletion of $B R C A 1$ showed $\mathrm{AI}$ at the $B R C A 1$ locus (Figure 1, Table 2). 4 of $8(50 \%)$ tumours revealed no relative $B R C A 1$ copy number change, yet 2 of these cases showed AI of BRCA1 (Figure 1, Table 2).

\section{Sporadic breast tumours}

14 unselected primary sporadic breast cancers were analysed for both BRCA1 and BRCA2 gene copy number changes by FISH. Physical deletion of $B R C A 1$ was detected in 6 cases $(6 / 14,43 \%)$. Loss of $B R C A 2$ was present in 7 cases $(7 / 14,50 \%)$. The concomitant deletion of both the $B R C A$ genes was detected by FISH in only 4 tumour samples $(4 / 14,29 \%)$. FISH data of the sporadic tumours are summarised in Table 3.

\section{DISCUSSION}

In the present study, we have studied $B R C A 1$ copy number changes and $\mathrm{AI}$ in $B R C A 2$ mutation tumours and vice versa. Only one study has been published previously on concomitant allelic loss of $B R C A 1$ and $B R C A 2$ in hereditary breast cancer. It involved 7 BRCA1-linked breast cancers, which showed combined $\mathrm{LOH}$ at
$B R C A 1 / 2$ loci at high level (Kelsell et al, 1996). Unfortunately, due to low incidence of $B R C A$ mutation tumours, studies of BRCA1/2 tumour features have been complicated by small sample size. Nevertheless, we were here able to study a reasonable number of BRCA1 cases and extend the study to concern also $B R C A 2$ tumours. Our results showed a high prevalence $(73 \%$ in BRCA1 tumours, Table $1 ; 67 \%$ in BRCA2 tumours, Table 2) of combined AI of $B R C A$ genes in both $B R C A 1 / 2$ tumours.

Taken together both $B R C A 1$ and $B R C A 2$ tumours available for AI analyses, concomitant allelic loss were detected in $12(71 \%)$ out of 17 cases. In contrast, the set of sporadic breast cancer showed loss of both $B R C A$ genes by FISH only in $4(29 \%)$ out of 14 tumours (Table 3 ). We have shown previously that AI of both $B R C A$ genes in sporadic breast cancer results mainly from physical deletion of the $B R C A$ genes, which is detectable by FISH. Therefore, we think that it is possible to compare hereditary AI data with FISH data from sporadic tumours. When the frequency of concomitant loss of $B R C A 1 / 2$ genes was statistically compared between hereditary and sporadic tumours, a significant difference between these two groups was found (Pearson $\chi^{2}=5.43$; $P<$ $0.02)$. Sporadic breast cancers reported in literature also have shown combined LOH of BRCA1 and BRCA2 at lower frequency (47\% in Kelsell et al, 1996; $32 \%$ in Silva et al, 1999) than in the hereditary tumours analysed here. In sporadic cancers, LOH/AI has frequently been seen at either BRCA1 or BRCA2 locus, at $17 \mathrm{q} 21(24-38 \%)$ or $13 \mathrm{q} 12-13(18-63 \%)$, respectively (Nagai et al, 1994; Hamann et al, 1996; van den Berg et al, 1996; Niederacher et al, 1997; Phelan et al, 1998). However, controversy exists whether $\mathrm{AI} / \mathrm{LOH}$ only at the single $B R C A$ locus is clinically significant in sporadic tumours (Beckmann et al, 1996, Bieche et al, 1997; Silva et al, 1999).

Our results imply that combined $\mathrm{AI}$ at the $B R C A$ loci might reflect a common pathway in tumour progression of hereditary breast cancers. In contrast, BRCA1/2 were concomitantly affected only in a minority of sporadic breast cancers, which further suggests that concomitant somatic loss of $B R C A$ genes is a typical feature of hereditary and not sporadic breast tumours.

Comparison of FISH and AI data makes it possible to distinguish whether allelic imbalance is due to a physical deletion or whether it is due to other genetic mechanisms. In general, $B R C A$ 
copy number changes and AI were in good agreement. However, in some cases AI was detected in the absence of actual gene copy number loss suggesting that deletion does not always explain AI. In theory, illegitimate homologus mitotic recombination could promote AI without any actual gene copy number losses, which are detected by FISH. However, whether these findings are truly linked to $B R C A$ mutation tumours, requires further studies.

\section{ACKNOWLEDGEMENTS}

Päivi Järvinen and Sari Toivola from the Laboratory of Cancer Biology are thanked for their technical assistance. Supported by: Finnish Academy of Sciences, Satakunta Cultural Foundation, Pirkanmaa Cancer Foundation, Finnish Cancer Society, Sigrid Juselius Foundation, Emil Aaltonen Foundation, Finnish Medical Foundation, Medical Research Fund of Tampere University Hospital.

\section{REFERENCES}

Albertsen HM, Smith SA, Mazoyer S, Fujimoto E, Stevens J, Williams B, Rodriguez P, Cropp CS, Slijepcevic P, Carlson M, Robertson M, Bradley P, Lawrence E, Harrington T, Sheng ZM, Hoopes R, Sternberg N, Brothman A, Callahan R, Ponder BAJ and White R (1994) A physical map and candidate genes in the BRCA1 region on chromosome 17q12-21. Nat Genet 7: 472-479

Beckman MW, Picard F, An HX, van Royen CRC, Dominik SI, Mosny DS, Schnürch HG, bender HG and Niederacher D (1996) Clinical impact of detection of loss of heterozygosity of BRCA1 and BRCA2 markers in sporadic breast cancer. Br J Cancer 73: 1220-1226

Bieche I, Nogues C, Rivoilan S, Khodja A, Latil A and Lidereau R (1997) Prognostic value of loss of heterozygosity at BRCA2 in human breast carcinoma. Br J Cancer 76: 1416-1418

Collins N, McManus R, Wooster R, Mangion J, Seal S, Lakhani SR, Ormiston W, Daly PA, Ford D, Easton DF and Stratton MR (1995) Consistent loss of the wild type allele in breast cancers from a family linked to the BRCA2 gene on chromosome 13q12-13. Oncogene 10: 1673-1675

Gudmundsson J, Johannesdottir G, Bergthorsson JT, Arason A, Ingvarsson S, Egilsson V and Barkardottir RB (1995) Different tumour types from BRCA2 carriers show wild-type chromosome deletions on 13q12-q13. Cancer Res 55: $4830-4832$

Gyapay G, Morissette J, Vignal A, Dib C, Fizames C, Millasseau P, Marc S, Bernardi G, Lathrop M and Weissenbach J (1994) The 1993-94 Genethon human genetic linkage map. Nat Genet 7: 246-339

Håkansson S, Johannsson O, Johansson U, Sellberg G, Loman N, Gerdes AM, Holmberg E, Dahl N, Pandis N, Kristoffersson U, Olsson H and Borg A (1997) Moderate frequency of BRCA1 and BRCA2 germ-line mutations in Scandinavian familial breast cancer. Am J Hum Genet 60: 1068-1078

Hamann U, Herbold C, Costa S, Solomayer EF, Kaufmann M, Bastert G, Ulmer HU, Frenzel H and Komitowski D (1996) Allelic imbalance on chromosome 13q: evidence for the involvement of BRCA2 and RB1 in sporadic breast cancer. Cancer Res 56: 1988-1990

Johannsson O, Ostermeyer EA, Hakansson S, Friedman LS, Johansson U, Sellberg G, Brondum-Nielsen K, Sele V, Olsson H, King MC and Borg A (1996) Founding BRCA1 mutations in hereditary breast and ovarian cancer in southern Sweden. Am J Hum Genet 58: 441-450

Kelsell DP, Spurr NK, Barnes DM, Gusterson B and Bishop DT (1996) Combined loss of BRCA1/BRCA2 in grade 3 breast carcinomas. Lancet 347: 1554-1555

Kerangueven F, Noguchi T, Coulier F, Allione F, Wargniez V, Simony-Lafontaine J, Longy M, Jacquemier J, Sobol H, Eisinger F and Birnbaum D (1997) Genome-wide search for loss of heterozygosity shows extensive genetic diversity of human breast carcinomas. Cancer Res 57: 5469-5474
Miki Y, Swensen J, Shattuck-Eidens D, Futreal PA, Harshman K, Tavtigian S, Liu Q, Cochran C, Bennett LM, Ding W, Bell R, Rosenthal J, Hussey C, Tran T, McClure M, Frye C, Hattier T, Phelps R, Haugen-Strano A, Katcher H, Yakumo K, Gholami Z, Shaffer D, Stone S, Bayer S, Wray C, Bodgen R, Dayananth P, Ward J, Tonin P, Narod S, Bristow PK, Norris FH, Helvering L, Morrison P, Rosteck P, Lai M, Barrett JC, Lewis C, Neuhausen S, CannonAlbright L, Goldgar D, Wiseman R, Kamb A and Skolnick MH (1994) A strong candidate for the breast and ovarian cancer susceptibility gene BRCA1. Science 266: 66-71

Nagai MA, Yamamoto L, Salaorni S, Pacheco MM, Brentani MM, Barbosa EM, Brentani RR, Mazoyer S, Smith SA, Ponder BA and Mulligan LM (1994) Detailed deletion mapping of chromosome segment 17q12-21 in sporadic breast tumours. Genes Chromosomes Cancer 11: 58-62

Neuhausen SL and Marshall CJ (1994) Loss of heterozygosity in familial tumours from three BRCA1-linked kindreds. Cancer Res 54: 6069-6072

Niederacher D, Picard F, van Roeyen C, An HX, Bender HG and Beckmann MW (1997) Patterns of allelic loss on chromosome 17 in sporadic breast carcinomas detected by fluorescent-labeled microsatellite analysis. Genes Chromosomes Cancer 18: 181-192

Phelan CM, Borg A, Cuny M, Crichton DN, Baldersson T, Andersen TI, Caligo MA, Lidereau R, Lindblom A, Seitz S, Kelsell D, Hamann U, Rio P, Thorlacius S, Papp J, Olah E, Ponder B, Bignon YJ, Scherneck S, Barkardottir R, BorresenDale AL, Eyfjord J, Theillet C, Thompson AM, Devilee P and Larsson C (1998) Consortium study on 1280 breast carcinomas: allelic loss on chromosome 17 targets subregions associated with family history and clinical parameters. Cancer Res 58: 1004-1012

Silva JM, Gonzalez R, Provencio M, Dominguez G, Garcia JM, Gallego I, Palacios J, Espana P and Bonilla F (1999) Loss of heterozygosity in BRCA1 and BRCA2 markers and high-grade malignancy in breast cancer. Breast Cancer Res Treat 53: 9-17

Smith AA, Easton DF, Evans DGR and Ponder BAJ (1992) Allele losses in the region 17q12-21 in familial breast and ovarian cancer involve the wild-type chromosome. Nat Genet 2: 128-131

Staff S, Nupponen NN, Borg A, Isola JJ and Tanner MM (2000) Multiple copies of mutant BRCA1 and BRCA2 alleles in breast tumours from germ-line mutation carriers. Genes Chromosomes Cancer 28: 432-442

Szabo CI and King M-C (1997) Population genetics of BRCA1 and BRCA2. Am J Hum Genet 60: 1013-1020

Tanner MM, Karhu RA, Nupponen NN, Borg A, Baldetorp B, Pejovic T, Ferno M, Killander D and Isola JJ (1998) Genetic aberrations in hypodiploid breast cancer: frequent loss of chromosome 4 and amplification of cyclin D1 oncogene. Am J Pathol 153: 191-199

Tavtigian SV, Simard J, Rommens J, Couch F, Shattuck-Eidens D, Neuhausen S, Merajver S, Thorlacius S, Offit K, Stoppa-Lyonnet D, Belanger C, Bell R, Berry S, Bogden R, Chen Q, Davis T, Dumont M, Frye C, Hattier T, Jammulapati S, Janecki T, Jiang P, Kehrer R, Leblanc JF, Mitchell JT, McArthur-Morrison J, Nguyen K, Peng Y, Samson C, Schroeder M, Snyder SC, Steele L, Stringfellow M, Stroup C, Swedlund B, Swensen J, Teng D, Thomas A, Tran T, Tran T, Tranchant M, Weaver-Feldhaus J, Wong AKC, Shizuya H, Eyfjord JE, Cannon-Albright L, Labrie F, Skolnick MH, Weber B, Kamb A and Goldgar DE (1996) The complete BRCA2 gene and mutations in chromosome 13q-linked kindreds. Nat Genet 12: 333-337

van den Berg J, Johansson O, Håkansson S, Olsson H and Borg Å (1996) Allelic loss at chromosome 13q12-q13 is associated with poor prognosis in familial and sporadic breast cancer. Br J Cancer 74: 1615-1619

Welcsh PL, Owens KN and King MC (2000) Insights into the functions of BRCA1 and BRCA2. Trends Genet 16: 69-74

Wooster R, Neuhausen SL, Mangion J, Quirk Y, Ford D, Collins N, Nguyen K, Seal S, Tran T, Averill D, Fields P, Marshall G, Narod S, Lenoir GM, Lynch H, Feunteun J, Devilee P, Cornelisse CJ, Menko FH, Daly PA, Ormiston W, McManus R, Pye C, Lewis CM, Cannon-Albright LA, Peto J, Ponder BAJ, Skolnick MH, Easton DF, Goldgar DE and Stratton MR (1994) Localization of a breast cancer susceptibility gene, BRCA2, to chromosome 13q12-13. Science 265: $2088-2090$ 